\title{
Rozwiązania techniczne w układach zasilania poprawiające efektywność energetyczną transportu szynowego
}

\begin{abstract}
$W$ artykule przedstawiono zagadnienia dotyczqce zużycia energii przez transport zelektryfikowany. Omówiono wplyw różnych czynników decydujacych o efektywności energetycznej transportu. Podkreślono rozwiqzania techniczne stosowane $w$ celu zmniejszenia zużycia energii transporcie poprzez zmniejszenie strat przesytowych i przetwarzania, a w szczególności zwiększajace wykorzystanie energii hamowania odzyskowego. Główny nacisk położony zostat na tematykę zastosowania falowników $w$ podstacjach trakcyjnych $w$ celu przesytu nadwyżkowej energii hamowania odzyskowego do sieci pradu przemiennego. Omówiono uwarunkowania tego rozwiazania, przedstawiono wyniki przeprowadzonych $w$ studium przypadku analiz oraz zasygnalizowano problemy, z jakimi moga spotkać się operatorzy systemów transportu elektrycznego przy wdrażaniu tego typu rozwiazania.
\end{abstract}

\section{Zużycie energii przez elektryczne pojazdy trakcyjne}

Ruchowi pojazdu przeciwstawiają się zewnętrzne siły - opory trakcji (ruchu) $W$ będące sumą tzw. zasadniczych (podstawowych) $W_{v}$ (niezależnych od trasy) i oporów lokalnych (dodatkowych) $W_{s}$., które występują na pewnych odcinkach trasy lub w pewnych określonych warunkach środowiskowych. Aby utrzymać ruch pojazdu ze stałą prędkością napęd pojazdu musi wytworzyć siłę trakcyjną równoważącą opory trakcji.

Zużycie energii $E_{t r}$ elektrycznej pobranej z sieci zasilającej dla pojazdów sieciowych (lub ze źródła energii na pokładzie w pojazdach autonomicznych) na potrzeby trakcyjne (pojazd pobiera również $\mathrm{z}$ sieci energię $E_{n}$ na potrzeby nietrakcyjne, urządzenia własne i pomocnicze) w poszczególnych fazach ruchu możemy wyznaczyć z następujących zależności:

- dla fazy rozruchu $E_{t r}$

$$
E_{t r}=t_{r} \cdot P_{m s r r} / \eta_{s r r}
$$

gdzie: $P_{m s r r}-$ moc mechaniczna średnia rozwijana na kołach $\mathrm{w}$ okresie rozruchu, $\eta_{s r r}$ - średnia sprawność przetwarzania energii elektrycznej w energię mechaniczną 'na kołach' w pojeździe w okresie rozruchu, $t_{r}$. - czas rozruchu;

- dla fazy jazdy z prędkością ustaloną $E_{t u}$ :

$$
E_{t u}=t_{u} P_{m u} / \eta_{s r u}
$$

gdzie: $P_{m u}-$ moc mechaniczna średnia rozwijana na kołach w okresie jazdy z prędkością ustaloną $(v=$ const $), t_{u}-$ czas jazdy z prędkością ustaloną, $\eta_{s r u}$ średnia sprawność przetwarzania energii elektrycznej w energię mechaniczną 'na kołach' w pojeździe w trakcie jazdy z prędkością ustalona,

- w fazie wybiegu: brak poboru energii na potrzeby trakcyjne,

- w fazie hamowania:

gdy stosowane jest hamowanie odzyskowe istnieje możliwość odzyskania energii - przetworzenie energii mechanicznej na elektryczną $E_{o}$ (praca generatorowa maszyny elektrycznej, pod warunkiem, że znajdzie się odbiór tej energii - inny pojazd pobierający prąd $z$ sieci lub zasobnik energii, w innym przypadku ta energia zostanie wytracona $\mathrm{w}$ rezystorze hamowania):

$$
E_{o}=1 / 2 m_{p}\left(v_{p}^{2}-v_{k}^{2}\right) \cdot \eta_{o}
$$

gdzie: $v_{p}$ - prędkość początku hamowania odzyskowego, $v_{k}$ - prędkość końca hamowania odzyskowego, $\eta_{o}$ - średnia sprawność przetwarzania energii mechanicznej w elektryczną w trakcie hamowania elektrycznego.

Jeśli czas hamowania wynosi $\mathrm{t}_{\mathrm{h}}$, to średnia moc hamowania wyniesie: $P_{s r h}=E_{o} / t_{h}$, zakładając zmienność tej mocy od $P_{h \max }$ do $0 \mathrm{w}$ czasie $t_{h}$, wtedy $P_{h \max }=2$ $P_{\text {sr } h}$.

Całkowite zużycie energii na potrzeby trakcyjne $\mathrm{w}$ danym cyklu jazdy pojazdu trakcyjnego wyniesie zatem:

$$
E_{t}=E_{t r}+E_{t u}-E_{o}
$$


Energię na potrzeby nietrakcyjne $E_{n}$ można wyznaczyć wykorzystując średnią moc potrzeb nietrakcyjnych $P_{n s r}$ dla cyklu jazdy:

$$
E_{n}=P_{n s r}\left(t_{r}+t_{u}+t_{w}+t_{h}\right)
$$

gdzie: $t_{w}$ - czas jazdy z wybiegu (wybiegiem).

Parametrem charakteryzującym energochłonność pojazdów trakcyjnych jest jednostkowe zużycie energii jze podawane $\mathrm{w}[\mathrm{Wh} / \mathrm{btkm}]$ lub [kWh] na [brutto tonokm] - (najbardziej ogólne) lub dla pojazdów pasażerskich $\mathrm{w}[\mathrm{Wh} /(1000$ pasażerokm)] albo (dla jednostek trakcyjnych i tramwajów) w [Wh/wozokm]. Jednostkowe zużycie energii może być podawane $\mathrm{z}$ uwzględnieniem lub nie energii potrzeb nietrakcyjnych $E_{n}$. Wyznacza się je wykorzystując dane dotyczące: całkowitej zużytej energii $E c=E_{t r}+E_{n}$ ), długości trasy $L$ i masy brutto $m$ (lub liczby pasażerów, liczby wozów). Poniżej podany jest wzór dla przypadku wyznaczania jze tylko na cele trakcyjne:

$$
j z e=E_{c} /(m L)[\mathrm{Wh} / \mathrm{btkm}]
$$

\section{Metody zmniejszenia zużycia energii $w$ transpor- cie elektrycznym}

2.1 Metody zmniejszania zużycia energii na cele trakcyjne pojazdu $[4,9,10,14,18,19,24,26,27,28]$

Zmniejszanie oporów ruchu można przeprowadzać na etapach:

- konstrukcji taboru (zmniejszenie masy i nacisku na oś, stosowanie łożysk tocznych, uresorowanie, stosowanie wózków miękko wpisujących się w łuki, tabor z wychylnym pudłem, opływowe kształty, budowa pociagów zespołowych zamiast lokomotywowych)

- budowy trasy (likwidacja łuków, odpowiednie profilowanie, tor bezstykowy eliminacja rozjazdów),

- eksploatacji taboru (regulacja hamulców, odpowiednie smarowanie części ciernych i zestawów kołowych, prawidłowe ciśnienie w kołach pojazdów drogowych, kontrola owalizacji kół, jazda z prędkością zbliżoną do średniej i wg zadanego, optymalnego dla trasy profilu prędkości, zapełnienie wagonów, prawidłowe zestawianie składów i stosowanie wagonów krytych, zamykanie drzwi i okien, wyłączanie pracujących na jałowo urządzeń w taborze) i trasy (smarowanie szyn na łukach, wymiana uszkodzonych i zużytych szyn).

\subsection{Oszczędności w układach przesyłu i przetwa- rzania energii}

Układ zasilania pojazdów w energię elektryczną jak i obwód główny mają istotny wpływ na sprawność dostawy i przetwarzania energii elektrycznej $[10,21,22,23,24,25]$. Podstawę stanowią straty przesyłowe, uzależnione od pobieranych prądów i rezystancji obwodów oraz straty $\mathrm{w}$ układach przetwarzania energii elektrycznej, które w ostatnich latach mają charakter energoelektronicznych układów łączeniowych. Od dawna w celu zmniejszenie strat przesyłowych zwiększano napięcie sieci trakcyjnej oraz zmniejszano rezystancję w obwodzie zasilania poprzez stosowanie:

- odpowiednich schematów zasilania (zasilanie dwustronne, stosowanie połączeń poprzecznych),

- większych przekrojów sieci trakcyjnej czy zmianę stosowanych materiałów (np. szyna o zmniejszonej rezystancji, stalowo-aluminiowa w metrze),

- poprawę charakterystyki źródła zasilania (zespoły o większej liczbie pulsów, wyższe napięcie zasilania podstacji).

\subsection{Zwiększenie wykorzystania energii hamowania odzyskowego}

Zastosowanie maszyny elektrycznej do napędu pojazdu pozwala wykorzystać możliwość jej pracy w trybie silnikowym i generatorowym $\mathrm{w}$ trakcie hamowania elektrycznego.

Z historii rozwoju trakcji elektrycznej wiadomo, że hamowanie elektryczne zaczęto stosować na liniach o znacznych profilach w celu zapewnienia efektywności hamowania i zmniejszenia zużycia hamulców mechanicznych, odzysk energii nie był wtedy istotny. W przypadku pracy w tunelach, hamowanie odzyskowe wpływa także pozytywnie na utrzymanie stałej temperatury, na skutek mniejszego użycia hamulców mechanicznych (np. klimatyzacja w metrze). Odzyskiwanie energii mechanicznej $w$ trakcie hamowania pojazdu jest obecnie rozwiązaniem powszechnie wykorzystywanym w napędach elektrycznych $[2,11,12,16,24]$.

Hamowanie odzyskowe daje w efekcie mniejsze zużycie energii, ale $\mathrm{w}$ przypadku rzadkich zatrzymań oszczędności ze stosowania hamowania odzyskowego nie będą zbyt wielkie (ok. kilku procent). Z kolei każde dodatkowe zatrzymanie na trasie zmniejsza nie tylko średnią prędkość, ale powoduje wzrost zużycia energii. Ponadto warunkiem uzyskania oszczędności jest, aby w pobliżu hamującego odzyskowo pociagu znajdował się pociąg pobierający energię $\mathrm{w}$ tym samym czasie.

W trakcji kolejowej ze względu na znaczne odstępy między pociaggami i nieregularny ruch dość często zdarzają się przypadki, że rekuperowana energia $\mathrm{z}$ hamującego pojazdu nie jest odbierana przez inny pojazd. Wynika to również $\mathrm{z}$ faktu, że rozruch lub jazda z poborem dużej energii trwają bardzo krótko w stosunku do całkowitego czasu przejazdu. Długość odcinków sekcyjnych oraz ograniczenie poziomów napięć w praktyce wyklucza wykorzystanie odzyskiwanej energii przez pociagi znajdujące na tej samej linii, ale daleko od pociagu hamującego.

Zwiększenie efektywności hamowania odzyskowego uzyskuje się przez: 
- umożliwienie wymiany pomiędzy pojazdami (odpowiedni rozkład jazdy, sterowanie zorientowane na wymianę energii pomiędzy pojazdami),

- zasobniki energii na pojazdach i w układzie zasilania $[1,2,5,11,12,16,27,28]$.

- falowniki $\mathrm{w}$ podstacjach prądu stałego $[3,6,7,8,11,13,15,17,20,25,27,28]$.

Przewidywanie rodzaju rozwiązania, celowości zastosowania, umiejscowienia ewentualnych zasobników/falowników energii nie jest możliwe bez przeprowadzenia szczegółowych analiz technicznych, ekonomicznych dla określonych przypadków. Rozwiązaniem korzystnym technicznie - szczególnie dla lokomotyw byłoby zastosowanie pokładowego zasobnika energii, który wspomagałby każdy kolejny rozruch po fazie hamowania. Oddzielnym zagadnieniem pozostaje analiza ekonomiczna takiego rozwiązania. Wykorzystanie np. superkondensatorów, jako pojazdowych zasobników energii, w sposób istotny zwiększa efektywność rekuperacji energii szczególnie w przypadku pojazdów o krótkich odcinkach między zatrzymaniami. W przypadku zasobników stacjonarnych dołączonych do układu zasilania sieci trakcyjnej nie nastąpi tak duża poprawa efektywności energetycznej. Znaczna część energii powstającej podczas hamowania nowoczesnego napędu zasilanego $\mathrm{z}$ sieci trakcyjnej jest przekazywana bezpośrednio do sieci trakcyjnej. Możliwości przyjmowania energii przez sieć nie są jednakowe w każdych warunkach. Zależą one między innymi od liczby pojazdów i ich chwilowego stanu pracy. W przypadku trolejbusów, które charakteryzują się wyższymi oporami ruchu, sytuacje, w których prostownikowe podstacje i sąsiednie pojazdy nie są $w$ stanie odebrać energii od hamującego pojazdu, zdarzają się rzadziej niż w przypadku tramwajów, metra czy kolei. Wysokie ceny zasobników w połączeniu z niską gęstością ruchu pojazdów sprawiają, że ich stosowanie, tylko w celu poprawy efektywności związanej z gromadzeniem energii powstałej podczas hamowania, może być nieopłacalne lub przynosić zwrot dopiero po bardzo długim okresie użytkowania. Wyznaczenie warunków granicznych opłacalności wymaga dokładnych analiz prowadzonych dla konkretnych rozwiązań technicznych zasobników jak i pojazdów oraz ich ruchu w obszarze zasilania. Dostarczanie energii do pojazdów za pomocą sieci trakcyjnej jest zagadnieniem złożonym. Istnieje wiele czynników mających wpływ na jakość dostarczanej energii oraz możliwości jej swobodnego przepływu od podstacji do pojazdu i z pojazdu do podstacji. Istotną rolę $\mathrm{w}$ tym zagadnieniu pełni zdolność podstacji do odbierania energii powstającej podczas hamowania, obecność innych pojazdów na tym samym odcinku zasilania oraz rezystancja elementów obwodów zasilania. Każdy z tych elementów ma znaczący wpływ na powstawanie strat.
Zasobnik energii elektrycznej stosowany do gromadzenia energii (głównie nadmiarowej, pochodzącej od hamujących odzyskowo pojazdów o napędzie elektrycznym) w celu ponownego wykorzystania zwiększa efektywność hamowania odzyskowego i zmniejsza zużycie energii oraz obciążenie systemu zasilania. Stosowany jest $\mathrm{w}$ pojazdach trakcyjnych i w podstacjach trakcyjnych, szczególnie trakcji miejskiej prądu stałego o niskim napięciu (jako zasobniki stosowane są: akumulatory, zasobniki wirujące - bezwładniki, superkondensatory). Zastosowanie zasobnika w pojeździe zapewnia pełne wykorzystanie energii hamowania. Eliminuje straty na jej przesył poprzez sieć trakcyjna. Mankamentem jest jednak ograniczenie masy zasobnika. W przypadku pojazdów następuje wzrost masy własnej co prowadzi do dodatkowych strat energii na transport zwiększonej masy. Zastosowanie zasobnika w podstacji trakcyjnej nie jest ograniczone dopuszczalną masą. Związane jest jednak ze stratami na przesył energii. Straty te są tym większe im dalej od podstacji znajdzie się hamujący pojazd trakcyjny.

\section{Zastosowanie falowników w podstacjach trak- cyjnych}

W trakcyjnych układach zasilania, charakteryzujących się gęstym ruchem, energia pochodząca $z$ hamowania odzyskowego jest przekazywana przede wszystkim do innych pojazdów. Niestety, nie zawsze sieć jest receptywna, co oznacza, że w chwili możliwości przekazania energii hamowania, nie ma na nią zapotrzebowania (żaden pociag nie pobiera energii). Takie przypadki stanowią główną podstawę do stosowania przekształtnikowych podstacji trakcyjnych, które wykorzystują energię pochodzacą z hamowania pociągów. Ocena celowości zastosowania falownika $\mathrm{w}$ podstacji wymaga wcześniejszego przeprowadzenia analiz technicznych i ekonomicznych.

W przypadku analizy technicznej należy uwzględnić szereg czynników wpływających na funkcjonowanie falownikowej podstacji trakcyjnej, są nimi m.in.:

- zaprojektowanie podstacji trakcyjnej $\mathrm{z}$ uwzględnieniem uwarunkowań (czy to podstacja nowa czy istniejąca, czy węzłowa czy szlakowa, jaki ruch jest prowadzony $\mathrm{w}$ obszarze podstacji) w celu uzyskania odpowiednio wysokiej efektywności energetycznej odzysku przy względnie małej liczbie przekształtników,

- algorytmu sterowania i charakterystyk przekształtników, ma to wpływ na parametry takie jak: receptywność układu, współczynnik mocy i zawartość wyższych harmonicznych w po stronie AC oraz ew. prądy wyrównawcze w obwodzie prostownik-falownik,

- harmoniczne w systemie zasilającym - zarówno falowniki jak i prostowniki powodują powstawanie wyższych harmonicznych po stronie AC i DC. 
- zapotrzebowanie mocy po stronie AC, wskazane jest, aby po stronie AC istniała możliwość poboru całej energii hamowania odzyskowego, jaką jest w stanie przesłać falownik,.

Wykorzystanie falownika wiąże się teoretycznie $\mathrm{z}$ wysoką efektywnością odzyskiwania energii hamowania pociagó́w. Należy jednak mieć na uwadze straty wynikające z dostawy energii z SE i jej przetwarzania w podstacji. Ilość energii i sprawność procesu odzyskanie - wykorzystanie energii jest porównywalna $z$ układem wykorzystującym zasobnik z superkondensatorami o bardzo dużej pojemności. Podstawowym warunkiem efektywnej pracy falowników jest obecność odbiorów po stronie prądu przemiennego pobierających wystarczająco dużą moc (gdyż w tym układzie nie ma możliwości gromadzenia energii). Drugim warunkiem efektywnego wykorzystania dostępnej w systemie DC nadwyżkowej energii hamowania jest wystarczajaca moc maksymalna falownika. Moc ta jest wyznaczana po określeniu mocy odzyskiwanej z pojazdów, a możliwej do dostarczenia do podstacji $\mathrm{w}$ da-nym kroku czasowym analizy i:

$$
\begin{aligned}
& \text { Jeżeli } \mathrm{P}_{\mathrm{pi}}>0 \mathrm{P}_{\mathrm{fi}}=\mathrm{P}_{\mathrm{tpi}} \\
& \text { Jeżeli } \mathrm{P}_{\mathrm{pi}} \leq 0 \mathrm{P}_{\mathrm{fi}}=0
\end{aligned}
$$

gdzie:

$\mathrm{P}_{\mathrm{pi}}-$ moc energii docierającej do podstacji $\mathrm{w}$ kolejnych krokach czasowych $i$

$\mathrm{P}_{\mathrm{fi}}$ - wymagana moc falownika w kolejnych krokach czasowych .

Poniżej przedstawiona jest zależność do wyznaczania wymaganej mocy falownika $\mathrm{P}_{\mathrm{fl}}$

$$
P_{f 1}=\operatorname{Max}\left\{P_{f i}\right\}_{i=1}^{i=m}
$$

Ilość energii $\mathrm{E}_{\mathrm{fli}}$ transferowana do $\mathrm{SE}$ AC w każdym kroku $i$ jest wyznaczana jako wartość uwzględniająca sprawność falownika.

$$
\begin{aligned}
& \text { Jeżeli } \mathrm{E}_{\mathrm{ri}}>0 \mathrm{E}_{\mathrm{fli}}=\mathrm{E}_{\mathrm{ri}} \cdot \eta_{\mathrm{fl}} \\
& \text { Jeżeli } \mathrm{E}_{\mathrm{ri}} \leq 0 \mathrm{E}_{\mathrm{fli}}=0
\end{aligned}
$$

gdzie:

$\mathrm{E}_{\mathrm{ri}}$ - ilość energii $\mathrm{w}$ podstacji pochodząca $\mathrm{z}$ hamowania odzyskowego

$\eta_{\mathrm{fl}}$ - sprawność falownika

Energia przetransferowana $\mathrm{E}_{\mathrm{fl}} \mathrm{W}$ trakcie okresu jednego analizowanego rozkładu jazdy jest równa sumie energii po uwzględnieniu sprawności elementów systemu.

$$
E_{f l}=\sum_{i=1}^{i=m} E_{f l i}
$$

Obniżenie mocy falownika $\mathrm{P}_{\mathrm{fj}}$ i transformatora w stosunku do wartości maksymalnej $\mathrm{P}_{\mathrm{fl}}$ zmniejszy ilość przetransferowanej energii.

Moc ta $\mathrm{P}_{\mathrm{fj}}$ jest określona jako część $\mathrm{O}_{\mathrm{pj}}$ mocy maksymalnej $\mathrm{P}_{\mathrm{fl}}$. gdzie:

$$
\mathrm{P}_{\mathrm{fj}=} \mathrm{P}_{\mathrm{fl}} \cdot \mathrm{O}_{\mathrm{pj}}
$$

$\mathrm{P}_{\mathrm{fj}}-$ moc maksymalna kolejnych wielkości falowników.

j- zmienna symboliczna opisująca kolejne zasobniki,

$\mathrm{O}_{\mathrm{pj}}<1$.

W trakcie obliczeń dla każdego kroku czasowego $i$ wyznaczana jest moc $\mathrm{P}_{\mathrm{fji}}$, która jest ograniczana przez moc maksymalną falownika $j$ :

$$
\begin{aligned}
& \text { Jeżeli } \mathrm{P}_{\mathrm{pi}}>\mathrm{P}_{\mathrm{fj}} \text { to } \mathrm{P}_{\mathrm{fji}}=\mathrm{P}_{\mathrm{fj}} \\
& \text { Jeżeli } \mathrm{P}_{\mathrm{pi}} \leq \mathrm{P}_{\mathrm{fj}} \text { to } \mathrm{P}_{\mathrm{fji}}=\mathrm{P}_{\mathrm{pi}}
\end{aligned}
$$

Ilość energii transferowana do systemu prądu przemiennego w każdym kroku czasowym wyznaczana jest jako wartość uwzględniająca sprawność falownika $\mathrm{j}$ :

gdzie:

$$
\mathrm{E}_{\mathrm{fji}}=\mathrm{E}_{\mathrm{ri}} \cdot \eta_{\mathrm{fj}}
$$

$\eta_{\mathrm{fj}}$ - sprawność falownika $\mathrm{j}$ i dołączonego do niego transformatora.

Energia przetransferowana do systemu AC $\mathrm{E}_{\mathrm{fj}} \mathrm{w}$ przypadku falownika $\mathrm{j} w$ trakcie okresu jednego rozkładu jazdy jest równa sumie energii po uwzględnieniu sprawności elementów systemu (równanie (12) analogicznie jak dla falownika o maksymalnej mocy) .

W wyniku analizy technicznej można oszacować możliwą do odzyskania przez falownik wielkość energii, która gdyby nie został zastosowany falownik zostałaby wytracona w rezystorach. W oparciu o analizę techniczną można przeprowadzić analizę finansowa, której wynikiem końcowym analizy jest roczny efekt finansowy wyrażony $\mathrm{w}$ pieniądzu, uzyskany po zastosowaniu rozwiązania oszczędzającego energię (tu falownik) przez właściciela instalacji (ponoszącego nakłady inwestycyjne) i jednocześnie będącego beneficjentem efektów inwestycji Wynik ten może być dodatni lub ujemny. Dodatkowym wynikiem jest liczba lat zwrotu nakładów inwestycyjnych.

W literaturze $[6,7,8,11,17,20]$ można znaleźć dane techniczne istniejących rozwiązań falowników, pozwalają na określenie wymaganych parametrów technicznych możliwych do zastosowania nowych rozwiązań. Mimo praktycznie braku gotowych rozwiązań produkowanych dla potrzeb odzysku energii w systemach $3 \mathrm{kV}$ DC (poza testowanymi w RPA czy oferowanymi przez estońską firmę ESTEL falownikami tyrystorowymi) możliwe jest oszacowanie oszczędności energetycznych. Inaczej jest z parametrami ekonomicznymi. Nie istnieją dotychczas produkowane rozwiązania urządzeń dostosowanych do systemu $3 \mathrm{kV}$ DC. Istniejąca eksperymentalna instalacja falownika na $3 \mathrm{kV}$ w RPA została wykonana wiele lat temu w technologii tyrystorowej. Obecnie stosuje się w czoperach jak i w falownikach pojazdowych zasilanych napięciem $3 \mathrm{kV}$ tranzystory IGBT. 
4. Studium przypadku analizy efektywności energetycznej falownika $w$ podstacji trakcyjnej $3 \mathrm{kV}$ DC

Wyniki analiz podawane w literaturze $[6,8,13,17,20$, $27,28]$ wskazują, że ok. $10 \div 20 \%$ energii pobranej z podstacji jest ponownie przekształcana przez falowniki, w przypadku niektórych linii kolejowych zarejestrowano efektywność na poziomie $8 \%$.

Jest wiele czynników wpływających na bilans mocy w systemie dostawy energii do pojazdów:

a) charakterystyka trasy:

- nachylenie,

- odległości pomiędzy stacjami,

b) organizacja ruchu:

- następstwa, masy i prędkości pociagów,

- synchronizacja czasu pomiędzy cyklem ruchu na torach różnych kierunków ruchu,

- stosowanie lub nie jazdy z wybiegu,

- ograniczenia prędkości,

c) stosowane rozwiązania techniczne:

- charakterystyki trakcyjne i hamowania pociągów,

- rozmieszczenie podstacji i rodzaj stosowanych prostowników (sterowane, niesterowane),

- rozmieszczenie falowników i ich charakterystyki,

- maksymalny dopuszczalny poziom napięcia na odbieraku pociagu,

- konfiguracja układu zasilania (odległości PTPT, zasilanie 1-str., 2-str., z kabiną i bez) i rezystancje sieci zasilającej.

W oparciu o analizy wstępne oraz wyniki przeglądu literaturowego można sformułować zalecenia dotyczące wyboru odcinków do analiz efektywności zastosowania odbiorników nadwyżkowej energii hamowania odzyskowego. Zasadniczo należy wziąć pod uwagę linie cechujące się:

a) ruchem dużej liczby pociągów zatrzymujących się i wyposażonych w układy hamowania odzyskowego (zwykle odnosić się to będzie do linii aglomeracyjnych i podmiejskich),

b) występowaniem odcinków z podhamowaniem / hamowaniem od dużych prędkości,

c) znacznym profilem pionowym (linie górskie), bez możliwości przekazania energii do innych pociągów (np. linie jednotorowe),

d) częstymi i krótkimi zatrzymaniami na przystankach, a nie na stacjach $\mathrm{z}$ długimi postojami (większe stacje $\mathrm{z}$ długimi postojami, tory postojowe plus hale postojowe powodują że cała energia kierowana jest na potrzeby własne innych pociagów),

e) relatywnie małymi odległościami między podstacjami i małymi rezystancjami sieci trakcyjnej - niskie straty energii w sieciach trakcyjnych.
W jednej z przeprowadzonych $\mathrm{w}$ Zakładzie Trakcji elektrycznej IME PW analiz przeprowadzono symulacje ruchu pociagów na odcinku jednotorowej linii górskiej o profilu dochodzącym do 30 promili.

Założono rozkład jazdy (rys. 1) z następującymi rodzajami pociagów:

P1 - zespół trakcyjny o mocy 4 MW (2 x ED74),

$\mathrm{P} 2$ - pociąg o masie $500 \mathrm{t} \mathrm{z}$ lokomotywą $6 \mathrm{MW}$,

$\mathrm{T} 1$ - pociag towarowy o masie $1250 \mathrm{t} \mathrm{z}$ lok. $6 \mathrm{MW}$.

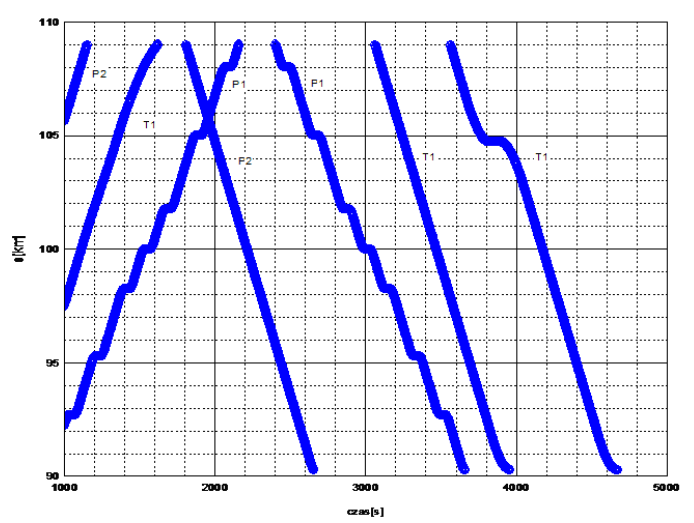

Rys.1 Przyjęty do analiz rozkład jazdy (linia 1-torowa), kierunek rosnacego profilu (TAM) od km 90 do $110 \mathrm{~km}$.

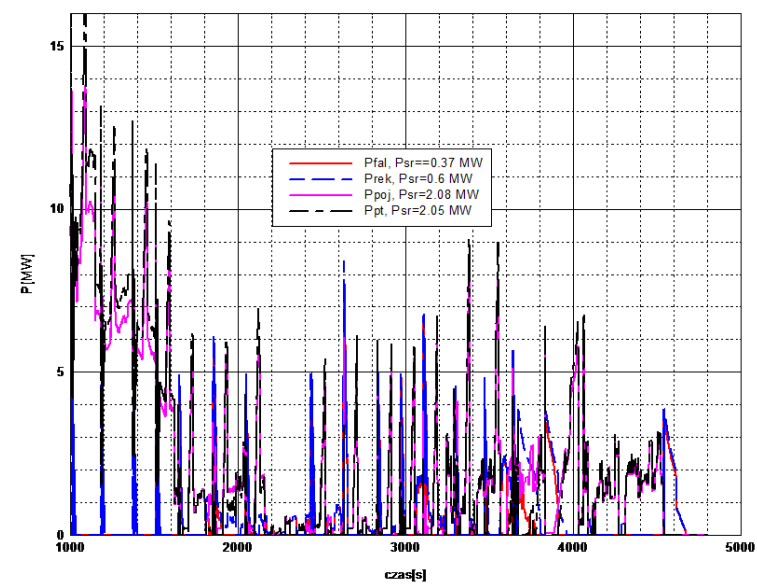

Rys. 2 Przebieg w funkcji czasu oraz wartości średnie mocy obciążeń systemu zasilania $3 \mathrm{kV}$ DC na odcinku - pobór mocy z podstacji $\mathrm{P}_{\mathrm{pt}}$ oraz moc chwilowa pobrana przez pojazdy $\mathrm{P}_{\mathrm{poj}}$, moc rekuperacji $\mathrm{P}_{\text {rek }}$ oraz moc dostarczona do falownika $\mathrm{P}_{\text {fal }}$.

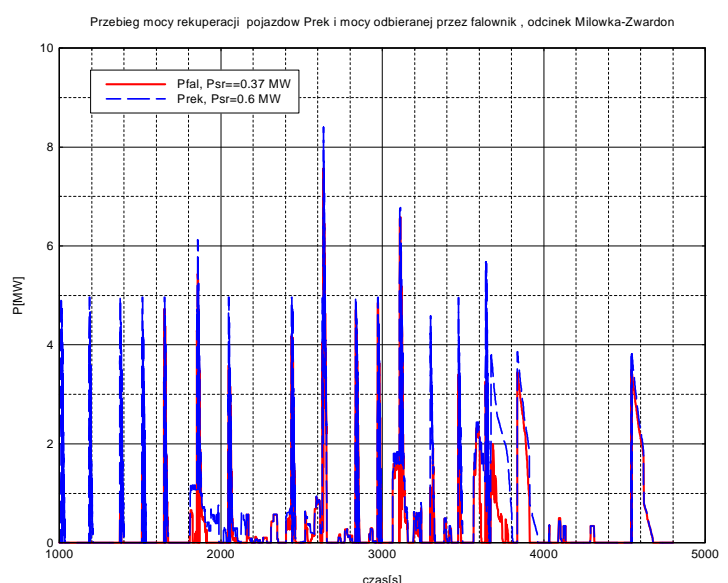

Rys.3 Powiększony przebieg mocy chwilowej rekuperacji $\mathrm{P}_{\text {rek }}$ oraz mocy dostarczonej do falownika $\mathrm{P}_{\mathrm{fal}}$. 


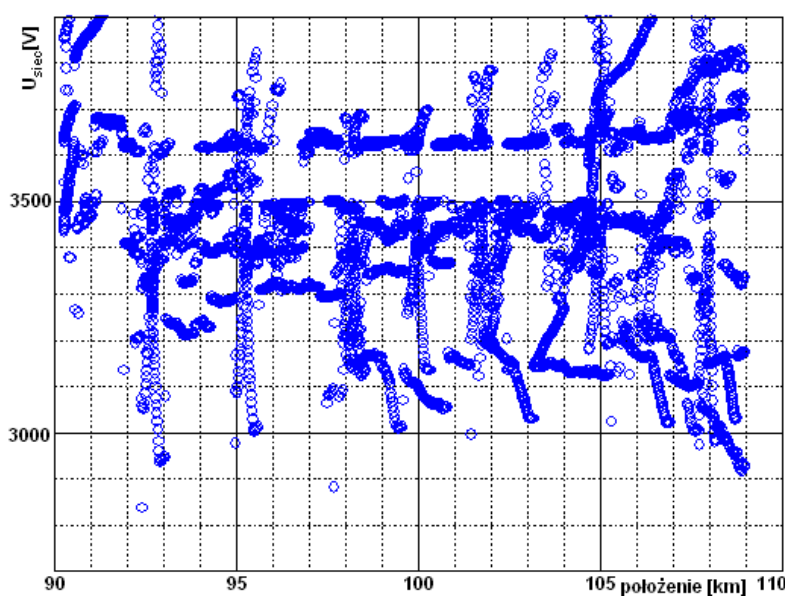

Rys.4 Napięcie w sieci trakcyjnej $\mathrm{U}_{\text {siec }} \mathrm{w}$ funkcji miejsca położenia pociagów.

Moce maksymalne $\mathrm{P}_{\mathrm{pt}}$ i $\mathrm{P}_{\mathrm{poj}}$ na odcinku zasilania przekraczają $15 \mathrm{MW}$, przy średnich ich wartościach na poziomie $2 \mathrm{MW}$ (rys. 2). Moce maksymalne rekuperacji $\mathrm{P}_{\text {rek }}$ przekraczały $8 \mathrm{MW}$, a moce rekuperacji $\mathrm{P}_{\text {fal }}$ na szynach DC falownika były poniżej $8 \mathrm{MW}$, przy średnich ich wartościach odpowiednio: $\mathrm{P}_{\text {rek }}=0,6 \mathrm{MW}$ i $\mathrm{P}_{\mathrm{fal}}$ $=0,37 \mathrm{MW}$. A zatem falownik byłby w stanie odebrać ponad $60 \%$ energii hamowania odzyskowego. $\mathrm{Z}$ kolei hamowanie odzyskowe stanowiło ok. 28\% energii pobranej z podstacji (w tym 17\% odebranej przez falownik w PT).

Warte zwrócenia uwagi jest, że (rys.2 i 3) przebieg mocy $\mathrm{P}_{\text {rek }}\left(\mathrm{i}\right.$ odpowiednio $\mathrm{P}_{\text {fal }}$ ) od ok. $1800 \mathrm{~s}$ czasu symulacji traci swój impulsowy charakter, pojawiają się dłuższe okresy oddawania energii, $\mathrm{z}$ tym że jest to przede wszystkim efekt długo trwających podhamowań pociągów jadących w kierunku POWRÓT (z góry), wynikający z dużego spadku trasy. Stanowi to istotny argument do zainstalowania falownika na tym odcinku. Na rys. 4 przedstawiono przebiegi napięć na odbierakach $\mathrm{U}_{\text {siec }} \mathrm{w}$ funkcji położenia pociągów. Zauważalne są dłuższe odcinki czasu hamowania odzyskowego (napięcia powyżej $3500 \mathrm{~V}$ ).

\section{Podsumowanie}

Biorąc pod uwagę aktualny stan zaawansowania i rozwiązań dla systemów, które mogłyby zostać zastosowane $\mathrm{w}$ trakcji elektrycznej można stwierdzić że:

- $\quad w$ trakcji elektrycznej prądu przemiennego ze względu na charakter stosowanego zasilania i dłuższe zasilane odcinki nadwyżkowa energia hamowania (ta, której nie są w stanie odebrać pociagi) może zostać przesłana bezpośrednio do sieci zasilającej $\mathrm{AC}$,

- z kolei w systemie prądu stałego DC, dla którego zgodnie z TSI dla kolei w Europie dla podsystemu Energia stosowanie urządzeń do stosowani hamowania odzyskowego jest zalecane, ale nie obowiązkowe:
- dla niskich napięć systemu zasilania (do 1,5 $\mathrm{kV}$ DC) istnieją rozwiązania, które pozwalają na zastosowanie zarówno falowników jak i zasobników energii (przede wszystkim superkondensatorów) [1,5,7],

- dla napięcia $3 \mathrm{kV}$ DC efektywnym ekonomicznie rozwiązaniem wydaje się być zastosowanie falownika do zwrotu energii do sieci energetycznej prądu przemiennego.

Stosowanie falowników w podstacjach wymaga jednak rozwiązania problemów dotyczących możliwości transferu energii do sieci AC. Znacznie prostsze to będzie, gdy operator systemu transportowego dysponuje wewnętrzną siecią AC o odpowiedniej zdolności odbioru energii. Gdy energia zwracana będzie do sieci lokalnego operatora systemu dystrybucyjnego (OSD) do rozwiązania będzie szereg zagadnień formalno-prawnych (np. możliwość transferu energii z systemu transportowego, gdy operator tego systemu nie ma formalnych uprawnień do odsprzedaży energii, zasady rozliczeń itp.) i technicznych (jakość energii - harmoniczne, wahania kierunku przepływu energii - dynamiczne przechodzenie od poboru do krótkotrwałego oddawania dużych mocy do sieci).

Mimo tego typu trudności, dla których trzeba będzie znaleźć rozwiązanie, wydaje się, że doświadczenia innych krajów (np. Hiszpanii) czy wprowadzona właśnie ustawa prosumencka pozwolą znaleźć satysfakcjonujący wszystkie strony kompromis. Pozwoli to na dalsze zwiększenie efektywności energetycznej transportu elektrycznego i zmniejszenie emisji zanieczyszczeń, coraz bardziej odczuwalnych szczególnie w środowisku polskich miast.

\section{Literatura}

1. ABB Review. ENVILINE ${ }^{\mathrm{TM}}$ ESS Energy Storage System for DC rail transportation. ABB. edition ABB Review. SEPTA's (Southeastern Pennsylvania Transit Authority) Wayside Energy Storage Project. ABB. edition 06.2014

2. Barrero R., Tackoen X., Van Mierlo J.- Improving energy efficiency in public transport: stationary supercapacitor based energy storage systems for metro network, IEEE Vehicle Power and Propulsion Conference (VPPC), September 3-5, 2008, Harbin, China

3. Dolecek R., Dobrovolny M. - Traction converting substation from viewpoint of feeding interlocking plant At Czech Railways..Traction Substation, Advances in Electrical and Electronic Engineering, 2008

4. Durzyński Z.-Podstawy metody wyznaczania parametrów energooszczędnej jazdy pojazdów trakcyjnych na obszarach aglomeracyjnych., Pojazdy Szynowe, 3/2011, s.1-5.

5. Hamacek Š., Bartłomiejczyk M., Hrbáč R., Mišák S., Stýskala $V$. Energy recovery effectiveness in trolleybus transport. Electric Power Systems Research, Vol. 112, 2014, p. 1-11. 
6. Henning P. H., Fuchs H. D., le Roux A. D., Mouton H. Du T. - A 1,5 MW Seven_Cell Series Stack Converter as an Active Power Filter and Regeneration Converter for a DC Traction Substation. IEEE Trans. On Power Electronics, vol. 23, no 5. Sept. 2008

7. Hesop All in one Energy\&Cost Saver, TRANS/PRSHT/TGS.HESOP/EN/01.2014/FR ALSTOM 2014.

8. Jang S., Choi C., Bae C., Song S., Won C.; Study of regeneraton Power control inverter for DC traction with active power filter ability, Industrial Electronics Society, 2005. IECON 2005. 31st Annual Conference of IEEE 6-10 Nov. 2005

9. Jarzębowicz L., Judek S., Karwowski K., Lipiński L., Miszewski M. - Kompleksowa analiza symulacyjna układu napędowego zespolu trakcyjnego. Czasopismo Techniczne. Elektrotechnika, 108, 2011, s. 121-131.

10. Jefimowski W. - Analiza porównawcza zużycia energii przez pociagi dużych prędkości $w$ zależności od stosowanego systemu zasilania.TTS Technika Transportu Szynowego 1-2/2014, s. 48-51,64

11. Konishi Takeshi, Tobito Masahiro - Fixed Energy Storage Technology Applied for DC. Electrified Railway (Traction Power Substation). Electrical Systems for Aircraft, Railway and Ship Propulsion (ESARS), Bologna 2012

12. Maciołek T., Drażek Z. - Zasobnik energii w tramwaju zmniejszajacy zużcie energii.TTS Technika Transportu Szynowego 11/2004, s. 54-57.

13. Mellitt B., Mouneimne Y.S., Goodman C.J.Simulation study of DC transit szstems with inverting substations, Proc. IEE Pt. B, No 2, vol. 131, pp. 38-50, March 1984

14. Mierzejewski L.,Szelag A. - Zagadnienia racjonalizacji zużycia energii elektrycznej $w$ systemie zelektryfikowanego transportu kolejowego. TTS Technika Transportu Szynowego 8/2001, s. 39-48.

15. Mierzejewski L., Szelag A.- Funkcjonowanie systemu elektroenergetyki trakcyjnej prqdu stałego $w$ warunkach eksploatacji taboru $z$ rekuperacja energii. TTS Technika Transportu Szynowego 6/2001, s. 43-51.

16. Pawełczyk M.: Rozwój systemów wykorzystujacych akumulację energii $w$ transporcie szynowym. Pojazdy Szynowe 2/2011, s.14-19.
17. Randewijk P.J., Enslin HR J.- Inverting DC Traction Substation with Active Power Filtering Incorporated, IEEE, 1995; pp 360-366

18. Rawicki S. - Semi-automatic control of tram vehicle with intent to attain minimum electric energy use, Przeglad Elektrotechniczny 7/2009, pp. 159-162.

19. Rawicki, S. - Energooszczędne przejazdy pojazdów tramwajowych $z$ silnikami indukcyjnymi przy zakłóceniach płynności ruchu i złożonym profilu trasy. Przeglad Elektrotechniczny 7a/2012, s. 235-241.

20. Suzuki T., DC-power supply system with inverting substations for traction systems using regenerative brakes. IEE Proc., vol. 129, Pt B, No 1, January 1982

21. Szelag A., Mierzejewski L. - Modelling and verification of simulation results in computer aided analysis of electric traction systems. International conference on computers in railways. COMPRAIL, 2000, Bologna.

22. Szelag A., Maciolek T.- A $3 \mathrm{kV} \mathrm{DC} \mathrm{electric} \mathrm{traction}$ system modernisation for increased speed and tra-ins power demand-problems of analysis and synthesis. Przeglad Elektrotechniczny 3a/2013, pp. 21-28

23. Szelag A., Mierzejewski L. - Systemy zasilania linii kolejowych dużch prędkości jazdy, TTS Technika Transportu Szynowego 11/2005,s. 80-90.

24. Szelag A., Mierzejewski L. -Ground Transportation Systems, Wiley Encyclopedia of Electrical and Electronics Engineering (1999), USA

25. Szelag A., Maciołek T., Drażek Z., Patoka M. Aspekty efektywności i energooszczędności w procesie modernizacji układów zasilania trakcji tramwajowej. Pojazdy szynowe,3/2011.s. 34-42.

26. Szelag A.- Zwiększanie efektywności energetycznej transportu szynowego. TTS Technika Transportu Szynowego 12/2008, s. 12-18.

27. WP4: Integrating carbon reduction in decision making and key business processes. Business Cases, Procurement, Financing and Capacity-Building. Ticket to Kyoto. June 2014

28. Zrównoważone $i$ inteligentne zarzadzanie energia dla inteligentnych systemów kolejowych $w$ Europie: zintegrowane podejście optymalizacyjne D1.1 Najważniejsze elementy sieci kolejowej i specyfikacja głównych podsystemów EC Contract No. FP7 314125 Project co-funded by the European Commission within the Seven Framework Programme (2007-2013). Raport $2013 \mathrm{r}$. 